\title{
PERBANDINGAN TERAPI MUSIK KLASIK DAN GENGGAM JARI TERHADAP PENURUNAN NYERI POST OPERASI APPENDIKTOMY DI RSUD KARANGANYAR
}

\author{
Rinda Anugrah Wati ${ }^{1}$, Yuli Widyastuti ${ }^{2}$, Nurul Istiqomah ${ }^{3}$ \\ ${ }^{1}$ Mahasiswa Program Studi DIII Keperawatan, ITS PKU Muhammadiyah \\ ${ }^{2,3}$ Dosen Program Studi DIII Keperawatan, ITS PKU Muhammadiyah
}

Email: rindaanugrah1@gmail.com

\begin{abstract}
ABSTRAK
Appendiktomy merupakan tindakan pembedahan yang dilakukan untuk memotong jaringan apendiks yang mengalami peradangan. Appendiktomy dapat menyebabkan terjadinya kontinuitas jaringan tubuh dan nyeri pada sistem saraf tepi. Manajemen nyeri non farmakologi dapat menggunakan terapi musik klasik dan genggam jari. Studi pendahuluan yang dilakukan di RSUD Kab. Karanganyar didapatkan angka kejadian appendiktomy pada bulan Juli-September 2019 sebanyak 48 pasien. Untuk mengetahui perbandingan terapi musik klasik dan genggam jari terhadap penurunan nyeri post operasi appendiktomy, maka digunakan metode penelitian Quasi experiment design dengan two group comparison pretest-posttest design, dengan teknik pengambilan sampel ialah accidental sampling. Dari hasil berdasarkan uji wilcoxon pada kelompok terapi musik klasik dan genggam jari didapatkan nilai $\mathrm{p}$ sebesar 0,038 , karena nilai $\mathrm{p}<0,05$ maka ada perbedaan intensitas nyeri sebelum dan sesudah diberikan terapi musik klasik dan genggam jari. Uji mann-whitney pada kelompok pre-test didapatkan nilai $\mathrm{p}$ masing-masing yaitu 0,650, karena nilai $\mathrm{p}>0,05$ maka dapat disimpulkan tidak ada perbedaan bermakna penurunan skala nyeri pada pasien post operasi appendiktomy yang diberikan genggam jari dan musik klasik.kedua Intervensi tersebut masing-masing memiliki keefektifan dalam mengurangi nyeri post appendiktomy. Pemberian terapi musik klasik dan genggam jari sama-sama efektif dalam penurunan nyeri post operasi appendiktomy.
\end{abstract}

Kata kunci: Pembedahan, Musik, Nyeri 


\title{
COMPARISON OF CLASSICAL MUSIC THERAPY AND FINGER CLOTHING ON THE DECREASE OF APPENDICTOMY PAIN OPERATIONS
}

\begin{abstract}
An appendectomy is a surgical procedure performed to cut the inflamed appendix tissue. Appendectomy can cause tissue continuity and pain in the peripheral nervous system. Non-pharmacological pain management can use classical music therapy and finger grips. A preliminary study conducted in RSUD Kab. Karanganyar found the incidence of appendectomy in July-September 2019 as many as 48 patients. To find out the comparison of classical music therapy and finger grips on the reduction of postoperative appendectomy pain, a Quasi experimental research method was used with two group comparisons pretest-posttest design, with the sampling technique is accidental sampling. From the results based on the Wilcoxon test in the classical music therapy group and finger grasping, the $p$ value was 0.038, because the $p$ value was $<0.05$, there was a difference in pain intensity before and after being given classical music therapy and finger grips. The Mann-Whitney test in the pre-test group obtained each $p$ value of 0.650 , because the $p$ value $>0.05$, it can be concluded that there is no significant difference in decreasing pain scale in postoperative appendectomy patients who are given finger grips and classical music. each of them has effectiveness in reducing post appendectomy pain. Classical music therapy and finger grips were equally effective in reducing postoperative pain in the appendectomy.
\end{abstract}

Keywords: Surgery, Music, Pain

\section{PENDAHULUAN}

World Health Organisation (WHO) (2010) menyatakan kejadian apendisitis didunia cukup tinggi. Angka kematian akibat apendisitis mencapai 21.000 jiwa, populasi laki-laki 11.000 jiwa dan 10.000 jiwa pada perempuan. Sebanyak 596.132 orang $(3,36 \%)$ di Indonesia dilaporkan menderita apendisitis pada tahun 2016, dan mengalami peningkatan menjadi 621.435 (3,35\%) pada tahun 2017 (Kemenkes, 2017). Jumlah kasus apendisitis di Jawa Tengah sebanyak 1.355 dan 190 diantaranya menyebabkan kematian (Dinkes Jateng, 2014).

Apendisitis merupakan kondisi dimana infeksi terjadi di umbai cacing dan dalam kasus ringan dapat sembuh tanpa perawatan, tetapi banyak kasus memerlukan laparatomi dengan penyingkiran umbai cacing yang terinfeksi. Apendisitis dapat diobati dengan pembedahan atau appendiktomy yaitu pemotongan untuk membuang apendiks yang meradang. Selain itu, biasanya penderita juga diberi antibiotik (Prihaningtyas, 2014). Appendiktomy 
merupakan suatu tindakan invansif membuka bagian tubuh yang akan ditangani dengan membuat sayatan pada pembedahan appendiktomy terbuka, insisi Mc Burney paling banyak dipilih oleh ahli bedah.

Nyeri post operasi dapat diatasi dengan intervensi manajemen nyeri yaitu dengan pemberian terapi farmakologi dan non farmakologi. Terapi farmakologi menekankan pada pemberian obat yang mampu menghilangkan sensasi nyeri (Rosdahl \& Kawalski, 2011). Terapi non farmakologi adalah terapi untuk menghilangkan nyeri dengan menggunakan teknik manajemen nyeri seperti: pemijatan, kompres hangat dan dingin, terapi musik, imajinasi terbimbing, hipnosis dan teknik relaksasi; seperti tarik napas dalam (Bulechek, dkk, 2013). Salah satu terapi non farmakologis untuk mengurangi nyeri adalah dengan mendengarkan musik klasik (Endarto, 2014).

Terapi musik merupakan salah satu tindakan untuk mengatasi nyeri, individu yang mengalami kesakitan akan merasa rileks saat mendengarkan musik. Musik memberikan distraksi dan disasosiasi opiate endogen dibeberapa fosi didalam otak, termasuk hipotalamus dan system limbik (Joyce $\&$ Hawks, 2014). New Zealand Society for Music Therapy (NZSMT) menyatakan bahwa terapi musik terbukti efektivitasnya untuk implementasi pada bidang kesehatan, karena musik dapat menurunkan kecemasan, nyeri, stress, dan menimbulkan mood yang positif (Economidou, 2012).
Teknik relaksasi genggam jari merupakan cara yang mudah untuk mengelola emosi dan mengembangkan kecerdasan emosional. Terdapat saluran atau meridian energy di sepanjang jarijari yang terhubung dengan berbagai organ dan emosi (Puwahang, 2011). Keadaan relaksasi secara alamiah akan memicu pengeluaran hormon endorfin atau hormon analgesik alami dari tubuh sehingga nyeri akan berkurang (Prasetyo, 2010). Penelitian yang dilakukan oleh Pinandita, dkk, menunjukkan bahwa relaksasi genggam jari efektif dalam mengurangi nyeri (Pinandita, dkk, 2012).

Dari hasil analisis kedua tehnik management nyeri dengan menggunkan terap music dan genggam jari mempunyai pengaruh untuk menurinkan nyeri, sehingga penelitian ini tertarik untuk membandingkan lebih efektif yang mana antara pemberian terapi musik klasik dan genggam jari.

\section{METODE PENELITIAN}

Penelitian ini merupakan jenis penelitian kuantitatif dengan menggunakan desain penelitian studi penelitian eksperimen semu (quasi eksperiment design). Desain penelitian yang digunakan adalah two group comparison pretest-postest design. Penelitian ini dilakukan di RSUD Kab. Karanganyar pada bulan Februari-Maret 2020. Sampel dalam penelitian ini adalah 10 responden dengan perbandingan 5 responden terapi musik klasik dan 5 responden genggam jari. Teknik sampling dalam penelitian ini adalah non probability sampling dengan teknik accidental sampling. 
Analisa data dilakukan dengan menggunakan program SPSS for Windows versi 19.0. Hasil pretest dan posttest dari masing-masing metode dianalisis dengan menggunakan uji wilxocon kemudian dilakukan uji mann whitney untuk mengetahui perbedaan variabel tidak berpasangan yaitu musik klasik dan genggam jari.

\section{HASIL PENELITIAN \\ Results \\ 1. Analisis Univariat}

Tabel 1. Distribusi Frekuensi Karakteristik Responden berdasarkan usia, pekerjaan dan

\begin{tabular}{lcc}
\multicolumn{3}{c}{ pengalaman Operasi (n=10) } \\
\hline Variabel & $\begin{array}{c}\text { Frekuensi } \\
(\mathrm{f})\end{array}$ & $\begin{array}{c}\text { Presentase } \\
(\%)\end{array}$ \\
\hline Usia & 1 & 10 \\
17-25 tahun & 4 & 40 \\
26-35 tahun & 1 & 10 \\
$36-45$ tahun & 3 & 30 \\
$46-55$ tahun & 1 & 10 \\
56-65 tahun & & \\
Pekerjaan & 1 & 10 \\
Mahasiswa & 1 & 10 \\
PNS & 3 & 30 \\
Swasta & 2 & 20 \\
Buruh & 3 & 30 \\
Petani & & \\
\hline PengalamanOperasi & & 80 \\
1 kali & 8 & 20 \\
2 kali & 2 & \\
\hline
\end{tabular}

Tabel 1. menunjukkan bahwa responden berdasarkan usia terbanyak adalah usia dewasa awal dengan rentang 26-35 tahun sebanyak 4 responden (40\%). Pekerjaan terbanyak adalah swasta dan petani sebanyak 3 responden (30\%), sedangkan berdasarkan pengalaman operasi sebagian besar

2. Distribusi Frekuensi Nyeri Sebelum dan Sesudah Terapi Musik Klasik dan Geggam Jari Distribusi frekuensi intensitas nyeri pretest dan post-test kelompok terapi musik klasik dan genggam jari dapat dilihat di tabel 2 berikut: adalah 1 kali yakni 8 responden $(80 \%)$.

Tabel 2. Distribusi Frekuensi Intensitas Nyeri Sebelum dan Sesudah Terapi Musik Klasik dan Genggam Jari

\begin{tabular}{llllllll}
\hline Variabel & N & Mean & Median & Mode & SD & Min & Max \\
\hline Pre-MK & 5 & 5,40 & 6,00 & 6 &, 894 & 4 & 6
\end{tabular}




\begin{tabular}{llllllll}
\hline Post-MK & 5 & 3,00 & 3,00 & 3 &, 707 & 2 & 4 \\
\hline Pre-GJ & 5 & 5,40 & 5,00 & 5 &, 548 & 5 & 6 \\
\hline Post-GJ & 5 & 2,80 & 3,00 & 2 &, 837 & 2 & 4 \\
\hline
\end{tabular}

Tabel 2. menunjukkan bahwa nilai mean nyeri sebelum diberikan terapi musik klasik dan genggam jari masingmasing sebesar 5,40 dimana intensitas nyeri yang dirasakan berada di skala sedang. Setelah diberikan terapi musik klasik dan genggam jari adalah 3,00 dan 2,80 dimana intensitas nyeri yang dirasakan berada di skala ringan.

\section{Analisa Bivariat}

Analisis bivariat $\backslash$ dalam penelitian ini untuk mengetahui perbandingan terapi musik klasik dan genggam jari terhadap penurunan nyeri post operasi appendiktomy. Sebelum dilakukan uji analisis, dilakukan uji normalitas data dengan menggunakan uji shapiro-wilk. Hasil dari uji normalitas didapatkan hasil yaitu: uji normalitas data pre-test dan post-test kelompok musik klasik $\mathrm{p}=0,046$ dan 0,325 , uji normalitas data pre-test dan post-test kelompok genggam jari $\mathrm{p}=0,006$ dan 0,314 , karena nilai $\mathrm{p}$ pre-test $<0,05$ maka data berdistribusi normal. Sehingga teknik analisa yang digunakan adalah uji statistik non parametrik dengan menggunakan wilxocon untuk menguji variabel berpasangan yaitu pre-test dan post-test kelompok musik klasik dan genggam jari. Uji yang dilakukan untuk mengetahui perbedaan variabel tidak berpasangan yaitu musik klasik dan genggam jari dengan menggunakan uji mann-whitney.

\section{a) Uji Wilcoxon}

Hasil analisa uji perbedaan 2 kelompok berpasangan pre-test dan post-test baik terapi musik klasik maupun genggam jari dapat dilihat di tabel 3. berikut:

Tabel 3. Hasil Uji Wilcoxon Kelompok Terapi Musik Klasik dan Genggam Jari

\begin{tabular}{lll}
\hline Kelompok & $\mathrm{Z}$ & $\mathrm{P}$ \\
\hline Pre-Test - & - & 0,038 \\
Post-Test & 2,07 & \\
MK & 0 & \\
\hline Pre-Test - & - & 0,038 \\
Post-Test GJ & 2,07 & \\
& 0 & \\
\hline
\end{tabular}

Tabel 3. menunjukkan bahwa nilai p sebelum dan sesudah dilakukan terapi musik dan genggam jari sebesar 0,038 karena nilai $\mathrm{p}<0,05$ maka dapat disimpulkan bahwa ada perbedaan intensitas nyeri sebelum dan sesudah diberikan terapi musik klasik dan genggam jari.

b) Uji Mann-whitney

Hasil analisa uji perbedaan 2 kelompok tidak berpasangan pre-test dan 
post-test terapi musik klasik

dilihat di tabel 4. berikut dan genggam jari dapat

Tabel 4. Hasil Uji Mann-Whitney Kelompok Post-Test

\begin{tabular}{lll}
\hline Variabel & $\mathrm{N}$ & $\mathrm{P}$ \\
\hline Post-test kelompok & 5 & 0,650 \\
musik klasik & & \\
$\begin{array}{l}\text { Post-test kelompok } \\
\text { genggam jari }\end{array}$ & & \\
\hline
\end{tabular}

Tabel 4. menunjukkan bahwa perbandingan nyeri post-test kelompok terapi musik klasik dan genggam jari pada pasien post operasi appendiktomy diperoleh nilai $\mathrm{p}$ yaitu 0,650 , karena p>0,05 maka diambil kesimpulan Ho diterima sehingga disimpulkan bahwa tidak ada perbedaan bermakna skala nyeri setelah diberikan terapi musik klasik dan genggam jari.

\section{PEMBAHASAN}

Karakteristik responden dalam penelitian ini membahas tentang usia, pekerjaan, dan pengalaman operasi. Kelompok usia terbanyak dalam penelitian ini adalah usia dewasa awal. Usia mempengaruhi tingkat kesehatan seseorang dimana dimana penyakit lebih banyak terjadi pada kalangan dewasa. Penelitian ini sejalan dengan penelitian yang dilakukan oleh Dani \& Calista, (2013) tentang karakteristik penderita apendisitis, dari penelitian tersebut didapatkan bahwa kelompok usia terbanyak adalah pada kategori dewasa awal. Hal ini juga sesuai dengan teori Gearhart \& Silen, (2013) bahwa insiden puncak apendisitis ialah pada dekade kedua dan ketiga kehidupan.
Mayoritas pekerjaan responden dalam penelitian ini adalah swasta dan petani. Hal ini sesuai dengan penelitian yang dilakukan oleh Gearhart \& Silen, (2013) yang menyatakan karyawan swasta memiliki presentase paling banyak daripada pekerjaan lainnya seperti pedagang dan buruh, hal ini dapat terjadi karena apendisitis lebih sering mengenai kelompok dengan sosial ekonomi menengah keatas seperti karyawan swasta.

Berdasarkan pengalaman operasi sebagian besar responden baru pertama kali menjalani operasi. Individu yang belum pernah mengalami operasi dapat dimungkinkan koping terhadap nyeri pasca operasi menjadi tidak bagus dan individu yang pernah mengalami nyeri sebelumnya akan lebih siap dan mudah mengantisipasi nyeri daripada responden yang mempunyai pengalaman sedikit tentang nyeri (Prasetyo, 2010).

Hasil penelitian diketahui terdapat penurunan nyeri setelah dilakukan terapi musik klasik terhadap pasien post appendiktomy. Hasil penelitian ini sejalan dengan penelitian yang dilakukan oleh Arif \& Sari, (2018), 
tentang efektivitas terapi musik mozart terhadap penurunan intensitas nyeri pasien post operasi fraktur. Pada penelitiannya tersebut dari 15 responden mengalami penurunan skala nyeri dari intensitas berat menjadi sedang dan ringan. Terapi musik merupakan salah satu penatalaksanaan nyeri dengan metode non farmakologis, yang mampu mempengaruhi persepsi dengan cara mendistraksi. Musik juga merangsang pelepasan hormon endorphin yang memberikan perasaan senang yang berperan dalam penurunan nyeri (Arif \& Sari, 2018). Rangsangan musik akan mengaktivasi jalur-jalur spesifik diberbagai area otak, seperti sistem limbik yang yang akan menyebabkan individu menjadi rileks saat mendengarkan musik (Hidayah, 2015).

Hasil penelitian diketahui terdapat perubahan nyeri sebelum dan sesudah diberikan genggam jari terhadap pasien post appendiktomy. Hasil penelitian ini sejalan dengan penelitian yang dilakukan oleh Sulung \& Rani, (2017), tentang teknik relaksasi genggam jari terhadap intensitas nyeri pada pasien post appendiktomi. Pada penelitiannya tersebut dari 10 responden mengalami penurunan intensitas nyeri sebelum dan sesudah teknik relaksasi genggam jari. Hal ini terjadi karena teknik relaksasi genggam jari memberikan suatu tindakan untuk membebaskan mental dan fisik dari ketegangan dan stress, sehingga dapat meningkatkan toleransi terhadap nyeri. Sepanjang jari-jari tangan terdapat saluran atau meridian energy yang terhubung dengan berbagai organ dan emosi (Puwahang, 2011).
Perlakuan relaksasi genggam jari akan menghasilkan impuls yang dikirim melalui serabut saraf aferen non nosiseptor, yang menyebabkan "pintu gerbang" tertutup sehingga stimulus nyeri terhambat dan berkurang (Pinandita, 2012).

Nyeri merupakan suatu kondisi berupa perasaan tidak menyenangkan bersifat subjektif karena perasaan nyeri berbeda pada setiap orang dalam hal skala atau tingkatannya (Hidayah \& Uliyah, 2014). Nyeri pada pasien post operasi disebabkan terjadinya kerusakan kontinuitas jaringan karena pembedahan yang akan menyebabkan pelepasan mediator kimia yang kemudian mengaktivasi nosiseptor dan memulai transmisi nosiseptik sampai terjadi nyeri (Economidou, 2012). Adanya perbedaan skala nyeri setelah pemberian terapi musik klasik dan genggam jari dikarenakan perbedaan persepsi setiap individu. Sebagian besar responden merasakan nyaman dan rileks setelah diberikan terapi musik klasik dan genggam jari namun terdapat responden yang cemas serta sulit untuk fokus saat diberikan terapi musik klasik dan genggam jari sehingga tidak mengalami perubahan intensitas nyeri. Prasetyo, (2010) menyatakan bahwa beberapa fakor yang mempengaruhi nyeri antara lain usia, jenis kelamin, perhatian, pengalaman operasi, dan makna nyeri. Hasil penelitian ini menujukkan bahwa metode non farmakologi yang dapat digunakan untuk mengurangi rasa nyeri pada pasien post appendiktomy adalah dengan menggunakan terapi musik klasik dan genggam jari dimana 
keduanya sama-sama efektif dalam menurunkan skala nyeri.

Hasil penelitian ini didukung oleh Djamal, dkk, (2015) dimana hasil penelitian menunjukkan adanya pengaruh yang signifikan antara terapi musik terhadap skala nyeri dengan uji statistik yaitu $\mathrm{p}=0,000$. Penelitian ini juga didukung oleh penelitian yang dilakukan oleh Arif \& Sari, (2018) tentang efektivitas terapi musik mozart terhadap penurunan intensitas nyeri pasien post operasi fraktur. Hasil penelitian menunjukkan bahwa terapi musik mozart efektif dalam penurunan intensitas nyeri post operasi fraktur dengan nilai $p=0,001$. Hal tersebut sesuai dengan teori Suryana, (2012) bahwa terapi musik digunakan sebagai motivasi, komunikasi, terapi kesehatan seperti nyeri. Musik yang menghasilkan alkaline adalah musik klasik yang lembut, instrumental, medatif dan musik yang membuat rileks dan tenang seperti musik klasik (Damayanti, dkk, 2014).

Hasil Aini, dkk, (2017) penelitian pengaruh teknik relaksasi genggam jari terhadap penurunan tingkat nyeri pasien post operasi appendiktomy di RSUD Dr. H. Soewondo Kendal menunjukkan bahwa teknik relaksasi genggam jari berpengaruh terhadap penurunan nyeri pada pasien post operasi appediktomy dengan nilai $\mathrm{p}=0,000$. Penelitian ini juga sesuai dengan pernyataan Astutik \& Kurlinawati, (2017) bahwa salah satu manfaat genggam jari adalah menurunkan nyeri. Hal ini disebabkan saat relaksasi genggam jari akan menghasilkan impuls yang dikirim melalui serabut saraf aferen non- nosiseptor, serabut ini mengakibatkan "gerbang" tertutup sehingga stimulus pada kortek serebi dihambat atau dikurangi akibat counter stimulasi relaksasi genggam jari, sehingga intensitas nyeri akan berubah. Relaksasi genggam jari dapat mengendalikan dan mengembalikan emosi yang akan membuat tubuh menjadi rileks (Pinandita, 2012).

\section{KESIMPULAN}

Berdasarkan hasil penelitian dan pembahasan tentang perbandingan terapi musik klasik dan genggam jari terhadap penurunan nyeri post operasi appendiktomy di RSUD Kab. Karanganyar pada 10 responden dapat disimpulkan bahwa terdapat pengaruh pemberian terapi music klasik untuk menurunkan nyeri pada pasien post operasi Appendiktomy dimana nilai $\mathrm{p}=$ 0,038 pada signifikan 5\%. Terdapat Pengaruh pemberian terapi genggam jari untuk menurunkan nyeri pada pasien post operasi Appendiktomy dimana nilai $\mathrm{p}=0,038$ pada signifikan $5 \%$. Hasil perbandinagn antara terapi music klasik dengan Terapi genggam jari dalam menurunkan nyeri Tidak ada perbedaan bermakna dimana nilai $\mathrm{p}=$ 0,650 atau $p>0,05$.Kedua intervensi tersebut sama - sama efektif menurunkan nyeri, sehingga dapat digunakan sebagai nursing action.

\section{UCAPAN TERIMAKASIH}

Terimakasih kami ucapkan kepada RSUD Karanganar dan ITS PKU Muhammadiyah Surakarta atas partisipasi dan kontribusinya dalam penelitian ini. 
DAFTAR PUSTAKA

Andarmoyo, S. (2013). Konep dan Proses Keperawatan Nyeri. Yogyakarta: Ar-Ruzz Media.

Aini., Tamrin., Rilasadi. (2017). Pengaruh Teknik Relaksasi Genggam Jari Terhadap Penurunan Tingkat Nyeri Pasien Post Operasi Appendiktomy di RSUD Dr. H. Soewondo Kendal.

Aribawa, M. (2017). Dasar Manajemen Nyeri \& Tatalaksana Multi Teknik Patient Controlled Analgesia. Jakarta: Sagung Seto.

Arif, M., Sari, Y. P. (2018). Efektifitas Terapi Muaik Mozart Terhadap Penurunan Intensitas Nyeri Pasien Post Operasi Fraktur. Jurnal Kesehatan Medika Saintika, volume 10 (1).

Asmadi. (2009). Teknik Prosedural Keperawatan:Konsep dan Aplikasi Kebutuhan Dasar Klien. Jakarta: Salemba Medika.

Astutik, P., Kurlinawati, E. (2017). Pengaruh Relaksasi Genggam Jari Terhadap Penurunan Nyeri Pada Pasien Post Sectio Caesarea Di Ruang Delima RSUD Kertosono. STRADA Jurnal Ilmiah Kesehatan, volume 6 (2): 30-37.

Black J. M., Jane H. H. (2014). Keperawatan Medikal Bedah: Manajemen Klinis Untuk Hasil
Yang Diharapkan Edisi 8 Buku 1. Jakarta: Salemba Medika.

Bulechek, G. M., Howard K. B., Joanne M. D., Cheryl. M. W. (2016). Nursing Intervention Classification (NIC) Ed. 6. Singapore: Elsevier.

Carsel, S. (2018). Metodologi Penelitian Kesehatan dan Pendidikan. Yogyakarta: Penebar Media Pustaka.

Dahlan, S. (2011). Statistik Untuk Kedokteran dan Kesehatan. Jakarta: Salemba Medika.

Damayanti., Jumaini., Sri. (2014). Efektifitas Terapi Musik Klasik Terhadap Penurunan Tingkat Halusinasi Pada Pasien Halusinasi Dengar di RSJ Tampan Prvinsi Riau. JOM PSIK, volume 1 (2).

Dani \& Calista P. Karakteristik pasien apendisitis akut di Rumah Sakit Immanuel Bandung periode 1 Januari 2013-30 Juni 2013. [Internet]. Repository Maranatha. 2013. [diakses: 14 Juli 2020]. Tersedia di: http://repository.maranatha.edu/id leprint/12568.

Dinas Kesehatan Jawa Tengah. (2014). Profil Kesehatan. Diakses pada 25 September 2019 dari www.dinkesjatengprov.go.id

Djamal, R., Sefty, R., Jeavery, B. (2015). Pengaruh Terapi Musik 
Terhadap Skala Nyeri Pada Pasien Fraktur di Iriana A RSUP. DR. R.D. Kandau Manado. E-Journal Keperawatan, volume 3 (2).

Economidou. E., Amalia, K., Victoria, G., Katerina, L. (2012). Does music reduce postoperative pain? A review. Health Science Journal. Volume 6, Issue 3 (July September 2012). https://www.hsj.gr/medicine/doesmusic-reduce-postoperative-paina-review.pdf (diakses pada 14 Juli 2020)

Endarto A., Isqomah., Wulandari. (2014). Perbedaan Intensitas Nyeri Pada Pasien Kanker Sebelum dan Sesudah Pemberian Terapi Musik Klasik di Rumah Sakit Telogorejo Semarang. Karya Ilmiah, volume 1.

Gearhart, S., Silen, W. (2013). Harrison Gastroenterologi \& Hepatologi. Jakarta: EGC.

Halawa, A., Timotius, B. M. A. (2018). Perbandingan Kompres Air Hangat Dengan Kompres Air Jahe Terhadap Low Back Pain Pada Lansia di Rumah Usiawan Panti Surya Surabaya. Jurnal William Booth. http://jurnal.stikeswilliambooth.ac .id/index.php/Kep/article/view/10 2 (diakses pada: 14 Juli 2020)

Handaya, A. Y. (2017). Deteksi Dini \& Atasi 31 Penyakit Bedah Saluran
Cerna (Digestif). Yogyakarta : Rapha Publishing.

Haniyah., Martyarin., Siti . (2016). Efektifitas Teknik Relaksasi Genggam Jari Terhadap Nyeri Post Sectio Cesarea di RSUD Ajibarang. MUSWIL IPEMI Jateng.

Hariyanto, A., Rini, S. (2015). “Asuhan Keperawatan Apendisitis". Dalam Rose KR (Ed.), Buku Ajar Keperawatan Medikal Bedah 1 : Dengan Diagnosis NANDA International. Yogyakarta: ARRuzz Media.

Hasmawa, I. K. (2016). Identifikasi Tingkat Kecemasan Pada Pasien Pre Operasi Di Rumah Sakit Umum Bahteramas Sulawesi Tenggara. Karya Tulis Ilmiah. Kendari: Politeknik Kementerian Kesehatan Kendari.

Herdman., Shigemi, K. (2018). NANDA-I Diagnosis Keperawatan: Definisi dan Klasifikasi 2018-2020. Jakarta: EGC.

Hermawan, I. (2019). Metodologi Penelitian Pendidikan Kuantitatif, Kualitatif dan Mixed Methode. Kuningan : Hidayatul Qur'an.

Hidayah, S., Veny. (2015). Perbandingan Efektivitas Terapi Musik Klasik Dengan Aromaterapi Mawar Terhadap Tekanan Darah Pada Penderita Hipertensi. JOM, volume 2 (2). 
Hidayat, A. A. (2014). Metode Penelitian Kebidanan dan Teknik Analisis Data: Contoh Aplikasi Studi Kasus. Jakarta: Salemba Medika.

Hidayat, A., Musrifatul, U. Pengantar Kebutuhan Dasar Manusia. Edisi 2. Jakarta: Salemba Medika.

Hill, R. T. (2011). Nursing From The Inside-Out: Living and Nursing From The Highest Point Of Your Consciousness. London: Jones and Barlett Publishers.

Humaera, R. (2016). Hubungan Ketidakcukupan Serat Terhadap Kejadian Apendisitis di Bandar Lampung. Digital Respiratory Unila, hal : 2324.

Jamaludin., Nur. K. U. (2017). Pengaruh Terapi Guided Imagery Dan Iringan Musik Klasik Terhadap Penurunan Nyeri Post Operasi Apendiktomi Hari 1 di Ruang Cempaka RSUD Sunan Kalijaga Demak. Jurnal Profesi Keperawatan, volume 4 (2).

Kementrian Kesehatan Republik Indonesia. (2017). Profil Kesehatan Indonesia. Jakarta: Departemen Kesehatan.
Noor, J. (2016). Metodologi Penelitian: Skripsi, Tesis, Disertai \& Karya Ilmiah. Jakarta: Prenada Media.

Notoatmodjo, S. (2018). Metodologi Penelitian Kesehatan. Jakarta: PT. Rineka karya.

Nuari, N. A. (2015). Buku Ajar Asuhan Keperawatan Pada Gangguan Sistem Gastrointestinal. Jakarta : CV. Trans Info Media.

Pinandita, I., Ery, P., Bambang, U. (2012). Pengaruh Teknik Relaksasi Genggam Jari Terhadap Penurunan Intensitas Nyeri Pada Pasien Post Operasi Laparatomi. Jurnal Ilmiah Kesehatan Keperawatan, volume 8(1).

Potter., Perry. (2014). Buku Ajar Fundamental Keperawatan : konsep, proses, dan praktik. Volume 2. Alih Bahasa : Reneta Komalasari, dkk. Jakarta : EGC.

Prasetyo, SN. (2010). Konsep dan Proses Keperawatan Nyeri. Yogyakarta: Graha Ilmu.

Prihaningtyas, R. A. (2014). Deteksi dan Cepat Obati 30+ Penyakit yang Sering Menyerang Anak. Yogyakarta: Media Pressindo.

Putri, D. M. P. (2019). Pengantar Riset Keperawatan. Yogyakarta: PT. Pustaka Baru.

Puwahang. (2011). Jari-Jaritangan. Diakses pada tanggal 25 
September 2019 dari http://titikrefleksi-pada-tangan.

Tsamsuhidajat. R., Wim D. J. (2010). At a Glance Ilmu Bedah Edisi 3. Jakarta: Erlangga.

Rehatta N. M., Elizeus, H., Aida, R. T (2019). Anestesiologi dan Terapi Intensif: Buku Teks KatiPerdatin. Jakarta: PT. Gramedia Pustaka Utama.

Riyanto. (2017). Metodologi Penelitian. Jakarta: Salemba Medika.

Rosdahl, C. B., Kawalski, M. T. (2015). Buku Ajar Keperawatan Dasar Edisi 10, Volume 3. Jakarta: EGC.

Sari, K. D., Ika P. (2013). Perbandingan Teknik Masase dan Terapi Musik Terhadap Penurunan Kecemasan Pada Ibu Bersalin Primipara Di Kecamatan Brebes Tahun 2013. Jurnal Ilmiah Kebidanan, vol. 4. No. 2.

Septiani, L. (2015). Analisa FaktorFaktor Yang Mempengaruhi Nyeri Pada Klien Fraktur di RS PKU Muhammadiyah Yogyakarta. Naskah Publikasi.

Smeltzer, S. C. (2018). Keperawatan Medikal-Bedah Brunner \& Suddarth, Ed. 12. Jakarta: EGC.

Suryana, D. (2012). Terapi Musik: Musik Therapy 2012. Bandung:
Create Space Independent Publishing Platform.

Suwartono. (2014). Dasar-Dasar Metodologi Penelitian. Yogyakarta: CV. Andi Offset.

Syamsuni. (2019). Statistik \& Metodologi Penelitian Dengan Implentasi Pembelajaran Android. Bojonegoro: CV. Karya Bakti Makmur.

Thomas, G. A., Ishak L., Adrian, T. (2016). Angka Kejadian Apendisitis di RSUP Prof. Dr. R. D. Kandou Manado Periode Oktober 2012-September 2015. Jurnal e-Clinic, volume 4(1): 232.

Wahyudi, A. S., Abd. W (2016). Buku Ajar Ilmu Keperawatan Dasar. Jakarta: Mitra Wacana Media.

Widyastuti, Y., Nabhani., Anik, E., Sulastri. (2016). Buku Keterampilan Keperawatan. Sukoharjo: CV. Jasmine.

Wirya, I., Margareth, D. S. (2013). Pengaruh Pemberian Massase Punggung dan Teknik Relaksasi Napas Dalam Terhadap Penurunan Intensitas Nyeri Pada Pasien Post Appendiktomy di Zaal C RS HKBP Balige Tahun 2011. Jurnal Keperawatan HKBP Balige, volume 1(1).

World Health Organization (WHO). (2010). Prevalensi Penyakit Apendiktomi. Diakses pada 
tanggal 25 September 2019 dari http// Angka Kejadian Apendiktomi.co.id
Zakiyah. A. (2015). Nyeri: Konsep dan Penatalaksanaan Praktik Keperawatan Berbasis Bukti. Jakarta: Salemba Medika. 